\title{
Implementation of Service Strategies on One Kecamatan One Centre of Entrepreneurship (OK OCE) Program in Jatinegara Sub-district East Jakarta
}

\author{
Noer Wachid ${ }^{1}$, Retnowati Wahyuning Dyas Tuti ${ }^{2}$ \\ \{wali.nurani@gmail.com ${ }^{1}$, retnowatiwdtuti@yahoo.com² ${ }^{2}$, \\ Universitas Muhammadiyah Jakarta, Indonesia ${ }^{1,2}$
}

\begin{abstract}
The condition of the open unemployment rate in Jakarta, which amounted to $7.14 \%$ in 2017 is quite alarming. Apart from the fact that this figure is above the national average (5.5\%). Responding to these demands, the OK OCE movement was then made in 2017. The program is implemented in all sub-districts in Jakarta, including Jatinegara sub-district. Therefore, this study was conducted to analyze the service strategy of the OK OCE program in Jatinegara Sub-District, East Jakarta. Rachmat theory [1] which consists of 4 service strategy implementations (program, budget, procedure, evaluation and control) is used in this study. While the method used is descriptive method with a qualitative approach. The results showed that the service strategy in the OK OCE program in Jatinegara Sub-district was not good enough due to several factors such as: The absence of a handling mechanism for people with low digital ability, not optimally utilizing large amounts of the budget, and not achieving the target of the OK movement registrants OCE or Integrated Entrepreneurship Development Program (PKT).
\end{abstract}

Keywords: Strategy, Service, OK OCE.

\section{Introduction}

Since 2015 Indonesia together with ASEAN countries has declared the MEA (Asean Economic Community). AEC is an economic system that involves cooperation between ASEAN countries. This system resulted in a pattern of freer trade between these countries. The positive impact of the AEC is being able to open up greater employment opportunities, so that more labor will be needed. In other words, this will also help reduce unemployment. Then MEA is also able to foster the competitiveness of each ASEAN country in the economic field.

While the negative impact of the MEA is the quality of Indonesian workers who are still unable to compete with foreign workers. In addition, the MEA also resulted in the recruitment of foreign workers by various companies in Indonesia. This can cause local (Indonesian) workers to not have a place in existing companies. Yet if they (Indonesian workers) are given space to work, it is not impossible they have more quality work than the foreign workers.

In essence, Indonesia has great potential in terms of quantity of human resources. According to the projections of the Central Statistics Agency (2019), Indonesia is predicted to experience a demographic bonus in 2030-2040, namely the number of productive age population (aged 15-64 years) is greater than the population of unproductive age (under 15 years old and above 64 year). During this period, the population of productive age is predicted to reach $64 \%$ of the total projected population of 297 million people. For Indonesia to reap 
maximum benefits from demographic bonuses, the availability of abundant productive-age human resources must be balanced with improvements in the quality of education and skills. In addition, also given adequate opportunities, both work opportunities and entrepreneurship.

However, reality is still not as expected. Based on data compiled from BPS [2], the unemployment rate in Indonesia is still quite high. Even in cities and provinces are not a guarantee for the community to be able to access employment as widely as possible. This is indicated by the following table:

Table 1. Open Unemployment Rates in 10 Provinces of Indonesia in the 2014-2017 Period

\begin{tabular}{lrrrr}
\multicolumn{1}{c}{ Province } & $\mathbf{2 0 1 4}(\mathbf{\%})$ & $\mathbf{2 0 1 5}(\mathbf{\%})$ & $\mathbf{2 0 1 6}(\mathbf{\%})$ & $\mathbf{2 0 1 7}(\mathbf{\%})$ \\
\hline Aceh & 9,02 & 9,93 & 7,57 & 6,57 \\
Sumatera Utara & 6,23 & 6,71 & 5,84 & 5,6 \\
Riau & 6,56 & 7,83 & 7,43 & 6,22 \\
Kepulauan Riau & 6,69 & 6,2 & 7,69 & 7,16 \\
DKI Jakarta & 8,47 & 7,23 & 6,12 & 7,14 \\
Jawa Barat & 8,45 & 8,72 & 8,89 & 8,22 \\
Banten & 9,07 & 9,55 & 8,92 & 9,28 \\
Kalimantan Timur & 7,38 & 7,5 & 7,95 & 6,91 \\
Sulawesi Utara & 7,54 & 9,03 & 6,18 & 7,18 \\
Papua Barat & 5,02 & 8,08 & 7,46 & 6,49 \\
Indonesia & $\mathbf{5 , 9 4}$ & $\mathbf{6 , 1 8}$ & $\mathbf{5 , 6 1}$ & $\mathbf{5 , 5}$ \\
\hline \multicolumn{5}{c}{ Source: $B P S(2018)[2]}$.
\end{tabular}

Based on the table 1, it can be stated that the Open Unemployment Rate (TPT) in 10 Provinces in Indonesia is still relatively high. Even still above the national average. One concern is the position of DKI Jakarta Province. In fact, its status as the Capital City should be a model for other Provinces to manage the labor market well. In the last 3 years (2015-2017), DKI Jakarta Province has always recorded a percentage of the open unemployment rate above the national average with a breakdown of 8.47\% (2015); 7.23\% (2016); and 6.12\% (2017).

On the other hand, in August 2018, the withdrawal in the last year (August 2017-August 2018 ), the proportion of workers with worker / employee status decreased from $68.29 \%$ to $65.66 \%$ (decreased $2.63 \%$ ). While in the status of self-employment there was an increase in the proportion of workers by $1.50 \%$, namely from $18.20 \%$ in August 2017 to $19.69 \%$ in August 2018. This is as shown in the graph below:

Based on the graph 1, it can be stated that there is a decrease in the percentage of the population who work as employees and an increase in the percentage of the population who are self-employed. This indicates that the interest of entrepreneurship in Jakarta residents has increased. Responding to this reality, the Provincial Government of DKI Jakarta sparked the One Center of One Kecamatan One Centre of Entrepreneurship program, hereinafter abbreviated as OK OCE. OK OCE is a community empowerment program to become an entrepreneur.

However, the OK OCE program requires a fit and proper service strategy to the people who have joined in this program so that comfort and high trust in the government are maintained. In addition, a quality service strategy is also needed so that people who have not yet joined the program are interested in participating in the OK OCE program that is promoted by the Provincial Government of DKI Jakarta. Based on these descriptions, this study seeks to 
answer the question "What is the Service Strategy of the OK OCE Program in Jatinegara SubDistrict, East Jakarta?".

Graph 1. Percentage of Working Population by Main Job Status 2017-2018

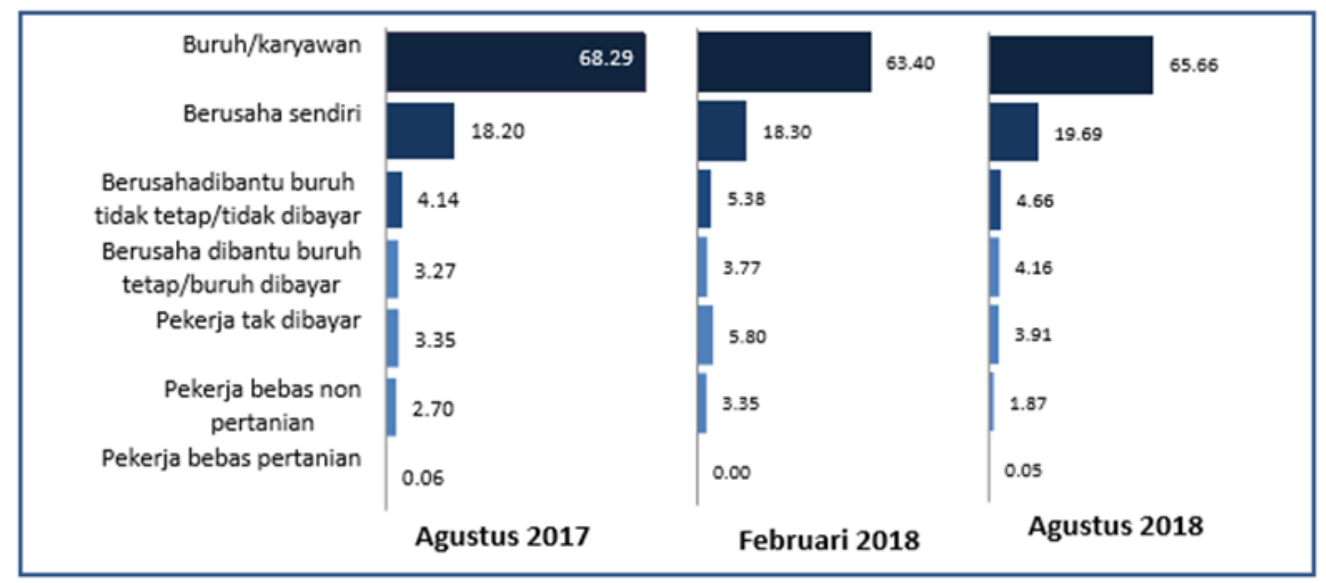

Source: BPS (2018) [2].

\section{Literature Review}

\subsection{Strategy Implementation}

Strategy is a form or plan that integrates the main objectives, policies and series of actions in an organization into a unified whole [3]. While, Bryson [4] defines strategy as a disciplined effort to produce fundamental decisions and actions that shape and guide what the organization does and why it should be done. On the other hand, Marrus [5] explains that strategy is a process of determining the plans of top leaders who focus on the long-term goals of the organization, accompanied by the preparation of a way or effort on how to achieve these goals.

Goldworthy \& Ashley explained 7 (seven) rules about formulating strategies, namely: 1) Strategies are made not only for the present, but must also interpret the future; 2) Strategic direction must be able to determine the plan and not vice versa; 3) Strategy must focus on competitive advantage, not solely on financial considerations; 4) Strategy must be applied from the top down, not from the bottom up; 5) Strategy must have an external orientation; 6) Flexibility is very essential in strategy; 7) Strategy must be centered on long-term results [6].

The word strategy is universal, so it can have semantic relations with various words and contexts, so that the word strategy can also be used in the context of tactics or ways to make a program successful. The program itself can be interpreted as a unit or unit of activity which is the realization or implementation of a policy, takes place in a continuous process and occurs in an organization involving a group of people Suharsimi \& Safruddin [7]. Related to the OK OCE program, a precise strategy is needed so that the objectives set from the program can be achieved. 
Cahyono said that the strategy has the following principles: 1) The strategy is implemented by considering the basic conditions of the organization and the prevailing market structure; 2) Strategy always involves form, amount and direction or purpose; 3) Strategy is a tool to achieve a goal in an ever-changing environment; 4) Strategy is conditional, which depends on the internal and external strengths of the organization; 5) Strategy is an intellectual activity that takes place in the mind of a manager; 6) Strategy is always carried out by looking at the competitor's strategy as a comparison to anticipate rapid and better changes; 7) Strategies are carried out to win the market and win consumers from competitors; 8) Strategies must be constantly updated and adjusted to changes and shifts in the consumer demand side; 9) Strategy can be a rediscovery that is very different from the methods carried out by competitors. The reinvention strategy became very effective when the paradigm in society began to accept new changes, for example changes in product design, product size, method of use and so on [8].

Strategies need to be implemented so that neither the vision nor the goals are utopian. Implementation of the strategy is the management process to realize strategies and policies in action through the development of programs, budgets, and procedures. This can be done through: 1) Program, i.e. a statement of activities or steps needed to complete a one-use plan. Programs involve organizational restructuring, organizational internal culture changes or the start of a new research effort; 2) Budget, which is a program expressed in terms of units of money, each program will be stated in detail in costs that can be used by management to plan and control. At the same time determine the financial performance report that shows the expected influence of the financial condition of the organization; 3) Procedures or standard operating procedures (SOP), namely a system of steps or techniques that sequentially describe in detail the way a task or work is completed part of an organization's programs; and 4) Evaluation and control, which compares the performance of the organization with the results expected by the organization. Performance is the final result of an activity [1].

\subsection{Service}

Zeithaml et al [9] say what is meant by service is: "Service is all economic activities whose output is not a physical product or construction is generally consumed at that time is produced and provides added value in the form (such as convenience amusement comfort or health). Basically, public service involves a very broad aspect of life and is also one of the elements that drives changes in the quality of Regional Government [10]. Another definition of public service was conveyed by Savas [11] that "the delivery of a service by a government agency uses its own employees". Public services can also be defined as services provided by the State or regions and state-owned companies to the community to meet their basic needs in order to create public welfare [12].

Gronroos in Fandy Tjiptono [13] states that there are 6 (six) dimensions of measuring service quality, namely: 1) Professionalism and skills. The customer is aware that service providers, employees, operational systems, and physical resources have the knowledge and skills needed to solve customer problems in a professional manner; 2) Attitudes and behavior. Customers feel employees pay attention to it and try to help in solving problems spontaneously and happy; 3) Accessibility and flexibility. The customer feels that the service provider, location, work, employees and operational systems are designed and operated in such a way that the service can easily access. It was also designed with the intention of being flexible in adjusting customer requests and desires; 4) Reliability and trustworthiness. The customer understands that whatever happens, the customer can trust everything to the service 
provider along with the employees and the system; 5) Recovery. The customer is aware that if there is an error or if something unexpected happens, the service provider will immediately take action to control the situation and find the right solution; 6) Reputation and credibility. The customer believes that the operation of the service provider is trustworthy and provides value or rewards that are consistent with his sacrifice.

Meanwhile, according to Sinambela [14], there are 6 (six) dimensions of the quality of public services consisting of: 1) Transparency. Be open, easy and can be accessed by all parties who need and are provided adequately and easily understood; 2) Accountability. Can be accounted for in accordance with statutory provisions; 3) Conditional. In accordance with the conditions and capabilities of service providers and recipients while adhering to the principles of efficiency and effectiveness; 4) Participatory. Encourage community participation in the delivery of public services by taking into account the aspirations, needs and expectations of the community; 5) Equal rights. Not discriminatory in the sense of not distinguishing ethnicity, religion, race, class, gender and economic status; 6) Balance of rights and obligations. Givers and recipients of public services must fulfill the rights and obligations of each party.

\section{Research Methods}

This research uses a qualitative approach, while the method used is descriptive method. As stated by Creswell [15], a qualitative approach provides flexibility to view social phenomena holistically. While the descriptive method focuses on the meaning (events, processes, and themes) in depth, which is then described in the form of words and images. The consideration of a qualitative approach with a descriptive method was chosen because this study wanted to describe in detail and interpret data to explain and analyze in depth the implementation of the strategy in the OK OCE program in Jatinegara District, East Jakarta.

All data obtained directly from informants in the field using interviews and observations. Data needed in this study includes primary and secondary data with details:

a) Primary data were obtained by researchers through field research from informants including: members of the PKT (Integrated Entrepreneurship Development), Head of the Cooperative Section, Small and Medium Enterprises (KUKM) of the East Jakarta KUKM Service Office, and PKT service assistants in the KUKMP Implementing Unit Jatinegara District, East Jakarta.

b) Secondary data in this study were obtained by studying documents, research journals, magazines, newspapers and textbooks. This secondary data includes various things, including geographical and demographic conditions, socioeconomic and cultural conditions of the study area. So, there are two sources of data in this study, namely informants and written documents.

\section{Results and Discussion}

OK OCE is a community empowerment program to become an entrepreneur. This idea has been developed by Hiramatsu, a former MITI official who was elected Oita Governor in 1979 under the name OVOP (One Village One Product), which was later adopted by many countries in the world such as Thailand (One Tambon One Product), Taiwan (One Town One 
Product), Malaysia (One District One Industry), Philippines (One Town One Product), Cambodia (One Village One Product) and in Indonesia which was initiated in 2006 by the Ministry of Industry which was then marked by the issuance of Presidential Instruction No. 6/2007 concerning policies to accelerate development of the real sector and empowerment of Micro, Small and Medium Enterprises (MSMEs) and Minister of Industry Regulation No. 78/M-Ind/Per/9/2007 concerning enhancing the effectiveness of developing Small and Medium Industries (IKM) through the One Village One Product (OVOP) approach that is interrelated to encourage local small and medium industry products to be able to compete in the global market [16].

10 regions selected by the Government to be developed with the OVOP approach are: Purwakarta (earthenware/decorative ceramics), Tasikmalaya (woven), Pekalongan (woven and wicker-weaving), Boyolali (copper handicrafts), Bantul (earthenware/decorative ceramics), Kulonprogo (woven), Bangli (woven bamboo), Tabanan (pottery/ornamental ceramics), West Lombok (pottery/ornamental ceramics), and Central Lombok (woven rattan). Both OVOP and OK OCE programs require active community participation from young, old, male, and female to get entrepreneurial mentoring in each district which then makes the community independent and prosperous entrepreneurs.

The OK OCE Entrepreneur Network Concept uses the C3P method namely Coaching, Training, Mentoring and Capital access. This is important to build an entrepreneurial mentality for those who are just testing a business idea or already have a business that continues to grow. The OK OCE Entrepreneurial Network will be part of an integrated solution to reduce unemployment, increase entrepreneurial skills with non-formal education and help citizens amid the high demand for basic prices which is expected to have implications for reducing poverty levels in DKI Jakarta. Then stabilization was made for representatives of members to move in 44 districts in Jakarta. One of the Subdistricts that implements the OK OCE program is Jatinegara District.

The implementation of the strategy in the OK OCE program in Jatinegara District, East Jakarta will be measured through 4 dimensions of the implementation of the Rachmat strategy [1], namely: 1) The program, namely the statement of activities or steps needed to complete the disposable planning. Programs involve organizational restructuring, organizational internal culture changes or the start of a new research effort; 2) Budget, which is a program expressed in terms of units of money, each program will be stated in detail in costs that can be used by management to plan and control. At the same time determine the financial performance report that shows the expected influence of the financial condition of the organization; 3) Procedures or standard operating procedures (SOP), namely a system of steps or techniques that sequentially describe in detail the way a task or work is completed part of an organization's programs; and 4) Evaluation and control, which compares the performance of the organization with the results expected by the organization.

\subsection{Program}

The OK OCE Program which started from a community movement was organized in an association called the OK OCE Movement (PGO), then the DKI Jakarta Provincial Government joined in synergy with PGO in the OK OCE movement. The support of the DKI Jakarta Provincial Government in the community's OK OCE movement is reflected in the Instruction of the Governor of DKI Jakarta Province number 152 of 2017 dated 15 December 2017 concerning the Formation and Development of Entrepreneurship. 
Deemed insufficient as a legal umbrella for the OK OCE movement, the Provincial Government of DKI Jakarta then issued Governor Regulation number 102 of 2018 on October 9, 2018 concerning Development of Integrated Entrepreneurship. Since the enactment of the regulation, the OK OCE movement has been officially adopted as a DKI Jakarta Provincial Government program called the Integrated Entrepreneurship Development Program or known as the PKT. The PKT program is intended for job seekers, those who need and have not yet gotten a job, beginner entrepreneurs, those who want to start their business and enter the class, namely micro entrepreneurs (street vendors) who want to be small entrepreneurs, small entrepreneurs who want to become entrepreneurs medium and medium entrepreneurs who want to become big entrepreneurs.

When referring to Pergub Number 102 of 2018, the goal of establishing PKT is quite good, namely to increase the quantity of entrepreneurs and develop integrated entrepreneurship. However, in practice there are still problems such as the PKT services being held online, starting from registration through the website pkt.jakarta.go.id, uploading data and verification, up to e-order registration, also online. This was stated by the Head of the Cooperative, Small and Medium Enterprises (KUKM) Section of the East Jakarta KUKM Office Sub-Department as follows:

"At present, all PKT services are run online, from the time of registration, the process of uploading data and verification."

A similar statement was also made by the PKT service assistant officer in the KUKMP Implementing Unit in Jatinegara District, East Jakarta stating that:

"Yes, now we have everything online, right. services carried out at the secretariat office are only on training and coaching. Coaching is mostly done online through the Whatsapp application, because each PKT member will join Whatsapp groups in which there are mentors and coaches from PGO. So that business assistance services can be done anytime and anywhere".

Based on the two statements, in essence the purpose of the service strategy implemented is quite good, by online all existing mechanisms. However, not every community who wants to participate in the OK OCE program understands the ins and outs of digital so that it is difficult to access PKT services. This is as demonstrated by an interview excerpt with one of the following CCP members:

"I find the system confusing, sir, I don't understand. Parents like me who know about online-online systems like that. There should be a direction from the Provincial Government of DKI Jakarta to overcome this problem".

Other statements also show the same tendency, as stated by other PKM members as follows:

"I regret why everything is made online like this, to the point that coaching is also made online. Though not all obstacles can be solved via online. For example, complaints, sometimes via online it is not responded, instead it is better to meet face to face so that it is clear to convey the complaint". 
Based on the description of the interview, it can be analyzed that the OK OCE movement strategy implemented through the Integrated Entrepreneurship Development (PKT) program is still not optimal. That is because the DKI Provincial Government generalized online services to the PKT program. In fact, there are several aspects that should be considered such as the level of digital capability of the community, the level of in-depth understanding of the programs and services that are online, and the selection of types of services that are online. The Provincial Government of DKI Jakarta needs to re-evaluate things that really do not need to be made online mechanism, or made an online mechanism, but there are still mechanisms that allow PKT members and prospective members to access services offline such as submitting complaints or criticisms and suggestions.

\subsection{The Budget}

The budget strategy is an effort that is stated in detail in the costs that can be used by management to plan and control, while determining the financial performance report that shows the expected influence of the financial condition of the organization. The OK OCE movement in the 2018 fiscal year was supported by a budget of Rp. 98 billion. But unfortunately, the huge amount of the budget has not been maximized properly. That's because a large portion of the budget is actually allocated for physical facilities and infrastructure as stated by members of DKI Jakarta DPRD Bestari Barus [17] as follows:

"The funds were apparently used more for the preparation of space, buying refrigerators (AC) and all kinds that are not directly related to the community".

These problems have increased along with the limited access to capital to the community. As further stated by Bestari Barus [17] below:

"I say to the media, the Okay Oce program is a lip service program. It is true that the list of 45 thousand people, but facilitated with access to new capital around the $300 \mathrm{~s}$ only".

Based on the interview excerpt, it can be justified that the implementation of the strategy on the budget aspect has not been implemented well. From a budget of Rp. 98 billion, most of it is allocated for the purchase of facilities and infrastructure to support programs such as: AC and others. In fact, it would be better if the budget could be allocated to other aspects that are far more important such as the capital aspect.

The capital aspect is an obstacle for PKT members because most of them do not yet have broad capital access from the DKI Jakarta Provincial Government. The results of the interview excerpt clearly show that only about 300 PKT members had access to capital for the OK OCE movement, the rest (around (44,700 members) were still unable to enjoy access to adequate capital services to start or develop their businesses.

\subsection{Procedure}

Procedures or standard operating procedures (SOP), which is a system of steps or techniques that sequentially describe in detail the way a task or work is completed part of an organization's programs. In the context of service strategy in the OK OCE movement, it is known as the Seven Sure Steps of Success or abbreviated as 7PAS which consists of: First, 
Registration. Done by creating an account at pktdev.jakarta.go.id and choosing 3 options namely Want to work, Want to Start a Business and Want to Increase Business [18]. PKT members will be given a 7PAS Status Card which will be monitored by the assistants in the District.

Based on observations, the initial appearance of the site pktdev.jakarta.go.id was quite good. This is as shown in the figure below:

Fig. 1. Display of PKT Registration
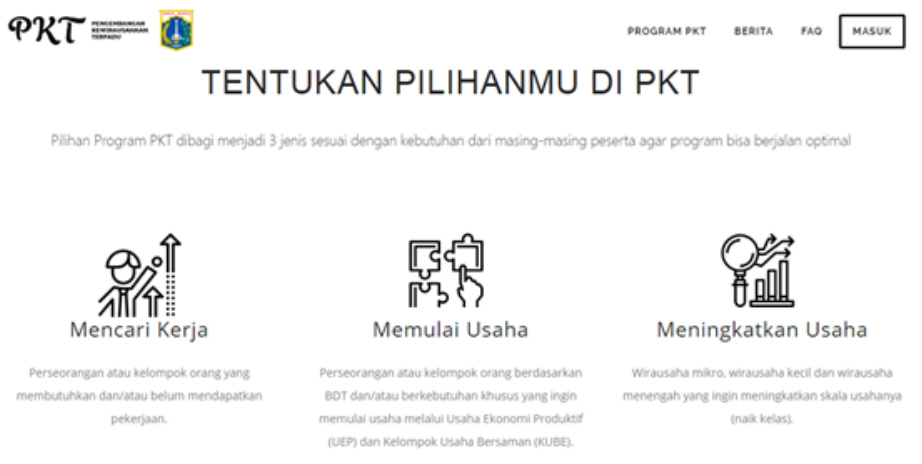

Source: pktdev.jakarta.go.id [18].

Second, Training. The first training material to be provided is material about "wanting to start a business". It starts with $5 \mathrm{~S}$ coaching method (Five Steps to Success) about entrepreneurial mentality (motivation and entrepreneurship). Advanced training curriculum will be adjusted to the level of business: a) Micro business towards Small Business: material will be given about making brands and logos, business cards and brochures , and sales / reseller strategy; b) Small Business towards Medium Business: knowledge will be given on how to make operational strategies, business plans, marketing strategies, entrepreneurial development orientation, improvement of business specialization capabilities and; c) Medium Enterprises towards Large Enterprises: given training on business development strategies, obtaining capital and exports.

Third, Assistance. PKT members will be included in the business assistance program through the KUKM and Trade Implementing Units in 44 Districts every working day, accompanied by Coaching Clinic services every Saturday at 8:00 am to 11:00 o'clock by voluntary Entrepreneur Coaches. Business cards and product / service brochures for members will be included in the Integrated Entrepreneurship Development Product Catalog through a curation process, which is then categorized based on the sub-district and the driving community. The driving community will help market the products and services of its target members with the concept of being a distributor. Products and services in the subdistrict catalog must have appropriate permits.

Fourth, Licensing. The KUKM Implementing Unit and the District Trade will help facilitate licensing and legality of members directed to free licensing and legality programs in accordance with the existing quota and help facilitate services for domicile, licensing and legality rental according to the needs of PKT members.

Fifth, Marketing. Products/Services for PKT members will be assisted by marketing through Retailers, Resellers, Franchises, Lokbin / Loksem, Online Stores, Bazzar/Exhibitions, 
and Exports where the marketing is determined based on the product curation process. Facilitation of product marketing is carried out by Regional Apparatuses as PKT implementers at least once a month through bazaar or other similar activities and at least every 3 months through organizing exhibitions of local, national and international entrepreneurs.

Sixth, Financial Reporting. PKT members will be trained to count turnover, profit and loss and prepare financial reports according to standards. The financial statements will later be used as a supplementary requirement for capital submission to banks and other capital institutions.

Seventh, Capital Facilitation. PKT members who already have financial reports will be helped to submit capital with three schemes, namely loan schemes, franchise schemes and other capital alternatives in collaboration with banks and other capital institutions that have collaborated with the PKT using the conventional and sharia capital systems.

\subsection{Evaluation and Control}

Evaluation and control, which compares the performance of the organization with the results expected by the organization. Related to this, based on data obtained from East Jakarta KUKMP Sub-dept., Information was obtained that the target of PKT registration in Jatinegara District in 2018 was not achieved. This is explicitly shown in the table below:

Table 3. Percentage of Working Population by Main Job Status 2017-2018

\begin{tabular}{|c|c|c|c|c|c|c|c|c|c|c|c|c|c|c|c|c|c|c|c|c|}
\hline \multicolumn{21}{|c|}{ BAHAN MONITORING DAN EVALUASI KEGIATAN } \\
\hline \multicolumn{18}{|c|}{ KOTA ADMINISTRASI JAKARTA TIMUR } & & & \\
\hline \multirow{2}{*}{\multicolumn{2}{|c|}{ Tanggal : 28 Juni 2019}} & & & & & & & & & & & & & & & & & & & \\
\hline & & \multicolumn{3}{|c|}{ Pendaftaran (P1) } & \multirow{2}{*}{\multicolumn{3}{|c|}{ Pelathan (P2) }} & \multicolumn{3}{|c|}{ Pendampingan (P3) } & \multicolumn{4}{|c|}{ Perizinan (P4) } & \multirow{2}{*}{\multicolumn{2}{|c|}{$\begin{array}{c}\text { Pemasaran (P5) } \\
\text { Realisasi }\end{array}$}} & \multirow{2}{*}{\multicolumn{2}{|c|}{$\frac{(\text { P6) }}{\text { Realisasi }}$}} & \multirow{2}{*}{\multicolumn{2}{|c|}{$\begin{array}{l}\text { Permodalan (P7) } \\
\text { Realisasi }\end{array}$}} \\
\hline \multirow[t]{2}{*}{ No } & \multirow{2}{*}{ Wilayah/Kecamatan } & \multirow{2}{*}{\begin{tabular}{|l|} 
Target \\
Target \\
\end{tabular}} & \multicolumn{2}{|c|}{ Realisasi } & & & Realisasi & \multirow{2}{*}{\begin{tabular}{|l|} 
Target \\
Target \\
\end{tabular}} & \multicolumn{2}{|c|}{ Realisasi } & \multicolumn{2}{|c|}{2018} & \multicolumn{2}{|c|}{2019} & & & & & & \\
\hline & & & 2018 & 2019 & \begin{tabular}{l|} 
Target \\
Target \\
\end{tabular} & 2018 & 2019 & & 2018 & 2019 & Target $\mathrm{k}$ & Realisas & Target / & Realisas & \multicolumn{2}{|c|}{\begin{tabular}{|l|l|} 
Realisasi \\
2018 & 2019 \\
\end{tabular}} & \multicolumn{2}{|c|}{\begin{tabular}{l|l}
\multicolumn{1}{c}{ Realisais } \\
2018 & 2019 \\
\end{tabular}} & \multicolumn{2}{|c|}{\begin{tabular}{|l|l|}
2018 & 2019 \\
2018
\end{tabular}} \\
\hline 1 & Cakung & 900 & 983 & & 800 & 716 & & 720 & 381 & & 200 & 322 & 560 & & 221 & & 191 & & . & \\
\hline 2 & Cipayung & 900 & 957 & & 800 & 800 & & 720 & 625 & & 200 & 176 & 560 & & 60 & & 10 & & . & \\
\hline 3 & Ciracas & 900 & 1.012 & & 800 & 800 & & 720 & 423 & & 200 & 207 & 560 & & 145 & & 40 & & 7 & \\
\hline 4 & Duren Sawit & 900 & 786 & & 800 & 629 & & 720 & 300 & & 200 & 135 & 560 & & 180 & & 84 & & . & \\
\hline 5 & Jatinegara & 900 & 713 & 386 & 800 & 713 & 200 & 720 & 713 & 70 & 200 & 130 & 560 & 20 & 66 & 100 & 150 & . & 22 & . \\
\hline 6 & Kramat Jati & 900 & 965 & & 800 & 640 & & 720 & 490 & & 200 & 90 & 560 & & 94 & & 44 & & 1 & \\
\hline 7 & Makasat & 900 & 807 & & 800 & 801 & & 720 & 371 & & 200 & 59 & 560 & & 95 & & 75 & & 7 & \\
\hline 8 & Matraman & 900 & 767 & & 800 & 729 & & 720 & 714 & & 200 & 129 & 560 & & 102 & & 101 & & 10 & \\
\hline 9 & Pasar Rebo & 900 & 678 & & 800 & \begin{tabular}{l|l|}
675 & \\
\end{tabular} & & 720 & 277 & & 200 & 66 & 560 & & 138 & & 2 & &. & \\
\hline 10 & Pulogadung & 900 & 751 & & 800 & 751 & & 720 & 288 & & 200 & 149 & 560 & & 99 & & 15 & & . & \\
\hline & JUMLAH & 9.000 & 8.419 & 386 & 8.000 & 7.254 & 200 & 7.200 & 4.582 & 70 & 2.000 & 1.463 & 5.600 & 20 & 1.200 & & 712 & & 47 & \\
\hline & Persentase & P1 & 93,54\% & $4,29 \%$ & P2 & $90,68 \%$ & $2,50 \%$ & P3 & $63,64 \%$ & $0,97 \%$ & P4 & $73,15 \%$ & P4 & $0,36 \%$ & & & & & & \\
\hline
\end{tabular}

Based on the table above, it is clear that the target of PKT program registration in 2018 cannot be achieved by Jatinegara District. From the target of 900 PKT members, only 713 PKT members were realized. This suggests that the PKT program's socialization to the community in Jatinegara District has not been fully implemented. In addition, people in Jatinegara sub-district may also feel that the programs in the OCE movement are less attractive to them. This needs to be comprehensively evaluated by the East Jakarta Government, especially in Jatinegara District. Evaluation efforts can be carried out among others through increasing the intensity of socialization to the community and increasing the 
quality of the socialization carried out in order to be more attractive to the people of DKI Jakarta to join the OK OCE movement.

\section{Conclusion}

Based on the results of the study it can be concluded that the service strategy in the OK Oc program in Jatinegara District, East Jakarta is not good enough. That is because there are still problems or deficiencies in a number of strategies such as: 1) The absence of a coping mechanism for people with low digital capabilities who want to join the OCE movement or Integrated Entrepreneurship Development (PKT) program; 2) Not optimal use of a very large amount of budget; 3) Not achieving the target of registering the OK OCE movement or Integrated Entrepreneurship Development (PKT) program in 2018.

Based on these conclusions, the suggestions for this research are as follows: 1) The Provincial Government of DKI Jakarta, particularly in the District of East Jakarta, must create online and offline mechanisms to accommodate communities who wish to register in the $\mathrm{OK}$ OCE movement and the CCP program, especially for people who have limited ability to access digital / online services; 2) There is a need for more substantive budget optimization, rather than priority allocation targeting the procurement of goods or infrastructure, it is better allocated to support access to capital for people participating in the OK OCE movement and the PKT program; 3) There needs to be an increase in the intensity of socialization to the community with the support of interesting program content to increase Jatinegara District community participation in the OK OCE movement and the PKT program.

\section{References}

[1] H. Rachmat and M. Si, "Manajemen Strategik," Bandung: Pustaka Setia, 2014.

[2] Badan Pusat Statistik, Tingkat Pengangguran Terbuka di 34 Provinsi di Indonesia. Jakarta: BPS, 2018.

[3] K. S. Cameron and R. E. Quinn, Diagnosing and changing organizational culture: Based on the competing values framework. John Wiley \& Sons, 2011.

[4] J. M. Bryson, Strategic Planning for Public and Non Profit Organizations: A Guide to Strengthening and Sustaining Organizational Achievement, vol. 48, no. 3. San Fransisco: Jossey-Bass Publishing Co, 2018.

[5] S. K. Marrus, "Desain penelitian manajemen strategik," Jakarta Rajawali Pers, 2010.

[6] M. A. J Salusu, Pengambilan Keputusan Stratejik. Gramedia Widiasarana, 2015.

[7] S. Arikunto and C. S. Abd, "Jabar.(2010)," Eval. Progr. Pendidikan, Pedoman Teor. Prakt. bagi Mhs. dan Prakt. Pendidikan. Jakarta Bumi Aksara.

[8] E. Yunus, "Manajemen Strategis, CV," Andi Offset. Yogyakarta, 2016.

[9] H. Hardiyansyah, Kualitas Pelayanan Publik: Konsep, Dimensi, Indikator dan Implementasinya. Gava Media, 2018.

[10] F. Fadli, M. Madani, and M. Idris, "Transparansi pemerintah dalam pelayanan sertifikat tanah di kota makassar," Otoritas J. ilmu Pemerintah., vol. 4, no. 2, 2014.

[11] E. Mouw, “Kualitas Pelayan Publik di Daerah,” J. Uniera, vol. 2, no. 2, pp. 92-103, 2013.

[12] M. Mutahhara, A. L. Prianto, and M. Muhammadiah, "TRANSPARANSI PELAYANAN IZIN INVESTASI USAHA DI KABUPATEN SINJAI,” Otoritas J. Ilmu Pemerintah., vol. 4, no. 2, 2014.

[13] F. Tjiptono, Komponen dan Dimensi Kualitas Jasa. Yogyakarta: Penerbit Andi, 2014.

[14] L. P. Sinambela, Reformasi pelayanan publik: teori, Kebijakan dan implementasi. Jakarta: Bumi Aksara, 2010. 
[15] J. W. Creswell, Research Design Pendekatan Kualitatif, Kuantitatif, dan Mixed. Yogyakarta: Pustaka Pelajar, 2014.

[16] C. . S. Pasaribu, Sosiologi Pembangunan. Bandung: Transito, 2005.

[17] C. S. Gunadha, Reza; Bhayangkara, "Rp 98 Miliar Dana Ok Oce, Mayoritas untuk Ruangan dan Beli AC," Minggu, 09 September 2018 15:00 WIB, 2018. [Online]. Available: https://www.suara.com/news/2018/09/09/150023/rp-98-miliar-dana-ok-oce-mayoritas-untukruangan-dan-beli-ac.

[18] PKT Jakarta, "Pengembangan Kewirausahaan Terpadu DKI Jakarta." [Online]. Available: https://pktdev.jakarta.go.id/index. 